\title{
Enterprise Risk Management, Risk Committee, and Earning Capacity of African Banks: A Comparative Approach
}

\author{
Augustine Chukwujekwu Odubuasi ${ }^{1}$, Nkechi Theresa Ofor ${ }^{2}$, Felix Ubaka Ilechukwu ${ }^{2}$ \\ ${ }^{1}$ Department of Accounting, Hezekiah University, Imo State, Nigeria \\ ${ }^{2}$ Department of Accounting, Chukwuemeka Odumegwu Ojukwu University, Anambra State, Nigera \\ Email: auglaw03@gmail.com, kechi4lv@yahoo.com, ilefelix1@gmail.com
}

How to cite this paper: Odubuasi, A. C., Ofor, N. T., \& Ilechukwu, F. U. (2022). Enterprise Risk Management, Risk Committee, and Earning Capacity of African Banks: A Comparative Approach. Modern Economy, 13, 51-68.

https://doi.org/10.4236/me.2022.131004

Received: December 3, 2021

Accepted: January 16, 2022

Published: January 19, 2022

Copyright $\odot 2022$ by author(s) and Scientific Research Publishing Inc. This work is licensed under the Creative Commons Attribution International License (CC BY 4.0).

http://creativecommons.org/licenses/by/4.0/

\begin{abstract}
This study did a comparative analysis on the effect of enterprise risk management (ERM), risk committee, on earning capacity of African banks. The study covered a study period of ten (10) years spanning from 2009 to 2018. The study covered Nigeria, Ghana, and South Africa. Data for the study were gotten from the fiscal reports of the banks under investigation. The study was analyzed using the panel data methodology. The study found that both ERM and risk committee efficiency have the greatest effect on the earning capacity of Nigerian firms $\left(R^{2}=60 \%\right)$ than the rest two countries. More so, our model has shown that South Africa has performed on a closer chase to Nigeria, in generating returns to the shareholders using the regressors mentioned above $\left(\mathrm{R}^{2}=56 \%\right)$. Finally, Ghana has performed the least so to say as the same variables generated or made the least input to $R O E\left(R^{2}=24 \%\right)$. Hence, we conclude ERM and risk committee are instrumental to improved earnings capacity of selected African banks. As such, the study recommends that regulators in African countries should enforce strict compliance and ensure that the ERM policies are implemented across banks in Africa. Lastly, corporate board should engage men that are knowledgeable in risk management.
\end{abstract}

\section{Keywords}

Enterprise Risk Management, Risk Committee, Earning Capacity, African Banks, Comparative Approach

\section{Introduction}

The universal financial crises of 2008 exposed the weaknesses in organizational risk management that led to the collapse of many companies like Enron and 
WorldCom, Parmalat and Cirio, which therefore, necessitated the strengthening of corporate governance practices (Florio \& Leoni, 2017). As a result of this, enterprise risk management (ERM), an approach that holistically controls risks at enterprise-wide level compared to the silo or piecemeal bases, was introduced to control the risks of the organisation. Consequently, the approval of this ERM framework by firms in developing nations of Africa had left practitioners and researchers in doubt if the approach had reduced the risks of the enterprise because of existence of scant literature from this emerging market (Africa). However, the audit committee was responsible for managing the risks of the enterprise which was becoming complex due to technological advancement, forces of globalization, rate of financial transactions, fluctuations in currency and commodity markets, and because of the overbearing responsibilities of the audit committee that includes internal control, financial reporting and regulatory compliance, Battaglia, Gallo and Graziano (2014) believe that recommendation was made to create an autonomous risk management committee, to specifically control the complex risks nature of the enterprise, and set the limit and risk appetite for the firm. Hence, it is not clear in literature if the creation of the separate RMC has helped to minimize the risks of the companies which will invariably improve the financial performance of companies that have separate RMC. More so, it becomes unavoidable to know the attributes (like expertise, composition, gender diversity, size and the frequency of meetings) of the risk committee that can enhance efficient formulation and administration of the risk policies of the organisation for a reduced risk exposure. Seeing that both the ERM and the RMC are novelties established to reduce and control risks of the enterprise, therefore, this surged inquisitiveness on us to know if these two risk management concepts could simultaneously work to minimize the risks of the firm and maximize the financial performance thereof. However, previous studies have dwelt so much on America, Europe and Asian countries of the world in investigating the effect of ERM adoption or implementation on firm performance. Such work in United States of America includes (Gordon, Loeb, \& Tseng, 2009; Kopia, Just, Gelmacher, \& Bubian, 2017; Mikes \& Kaplain, 2014), in Europe (Anton, 2018; Florio \& Leoni, 2017; Lukianchuk, 2015), in Asian countries (Husaini \& Saiful, 2017; Lai \& Samad, 2011; Ramlee \& Ahmad, 2015; Rao, 2018). Some other scholars like (Udoka \& Orok, 2017) undertook the same subject matter in Nigeria. Though among the ones that had studied African nations none had taken broad samples of African nations the way Rao (2018) studied the same subject on Gulf Cooperation Council that consists of six nations, which creates a gap in literature.

Again why most of the studies have focused on the characteristics of the companies adopting ERM (Gordon, Loeb, \& Tseng, 2009; Liebenberg \& Hoyt, 2003; Mikes \& Kaplain, 2014; Pagach \& Warr, 2007; Yazid, Hassan, Mahmood, Rashid, Salleh, Ghazali, \& Mahmod, 2018), others had concentrated on the determinants of ERM implementation (Dabari \& Saidin, 2016; Kakanda, Slim, \& Chandren, 
2016; Lai \& Samad, 2011; Onder \& Ergin, 2012; Paape \& Spekle, 2012), whereas some more studies looking at the effect of ERM on firm performance (Alawattegama, 2018; Altanashat, Dubai, \& Alhety, 2019; Anton, 2018; Husaini \& Saiful, 2017; Lukianchuk, 2015; Pagach \& Warr, 2010; Rao, 2018). On the other hand, Ahmed, Abdullahi, Mohamed and Umar (2018); Zemzem and Kacem (2014) in Tunisia and Nigeria respectively did investigate the characteristics of risk committee that could improve performance of firms. However, just few works such as Rao (2018) in Gulf Corporation Council; Kommunuri, Jandug and Vesty (2014) in USA, and Husaini and Saiful (2017) in Indonesia had looked at how board mechanism reduces the risk of the enterprise, and as such increase its performance. Therefore, Africa is an emerging market that should establish a solid financial system for faster and robust regional economic growth needs to device an effective approach to handle all the prospective risks that may confront its banking sector. Hence, it becomes imperative to explore the possibility and extent of risk reduction that could be achieved in Africa, by combining enterprise risk management model with risk management committee. On this note, the study investigated the impact of enterprise risk management and risk management committee on the earnings strengths of banks in Africa.

\section{Literature Review}

\subsection{Conceptual Review}

The term enterprise risk management (ERM) in its simplest term is aggregate approach to treating all the organization's risk which is developed as a result of the failure of the conventional traditional risk methods, which treats risk in a piecemeal or the departmental based approach. That brings to limelight the definition by Zuo, Isa and Rahman (2017) that ERM requires a company-wide perspective to be taken in identifying, assessing, and managing risk instead of the traditional "silo" based approach to managing risk.

Notwithstanding, ERM had been measured from different perspectives. Firstly, ERM had been measured using dummy variable, which allowed researchers assign I when it is perceived to have adopted or implemented ERM otherwise 0, and the implementation, adoption or presence of ERM is indicated by searching for key-terms like, "strategic risk management", "corporate risk management", "consolidated risk management", "holistic risk management", "integrated risk management", "risk management committee", "risk committee", and "chief risk officer" (Abdullah, Janor, Hamid, \& Hamid, 2017; Anton, 2018; Florio \& Leoni, 2017; Husaini \& Saiful, 2017; Nasir, 2018; Pagach \& Warr, 2007; Rao, 2018). Secondly, the other researchers (Alawattegama, 2018; Altanashat, Dubai, \& Alhety, 2019; Teoh, Lee, \& Muthuveloo, 2017) had chosen to measure ERM by constructing questionnaire based proxy on the eight (8) ERM functions (Internal Environment, Risk Identification, Objective Setting, Risk Assessment, Risk Response, Control Activities, Information \& Communication, and Monitoring) as contained in the COSO (2004) integrated framework. Thirdly, some more au- 
thors (Gordon, Loeb, \& Tseng, 2009; Ramlee \& Ahmad, 2015; Tseng, 2007; Zuo, Isa, \& Rahman, 2017) proxy ERM on the bases of the COSO (2004) four (4) basic objectives of ERM which include Strategy, Operation, Reporting and Compliance. This current study perceives the last measure as being the most suitable because the accomplishment of the four objectives invariably indicates adoption and efficiency of ERM practice. Hence, ERM is measured using the four objectives of ERM as laid down by COSO (2004). However, the ERM Index (ERMI) below is derived from the sum of the indicators already discussed. Hence: ERMI $=\Sigma$ Strategy $+\Sigma$ Operations $+\Sigma$ Reporting $+\Sigma$ Compliance.

Omondi and Muturi (2013) opined that earning capacity can be measured by growth in profitability, production capacity, sales growth and utilization of the capital and financial resources. Consequently, Naz, Ijaz and Naqvi (2016) present that the best way to evaluate earning capacity is by using ratios. Nevertheless, the commonly used earning capacity indicators for assessment of enterprise risk management by the previous researches reviewed include; Return on Assets (ROA) as seen in the work of (Ramlee \& Ahmad, 2015; Abdullah, Janor, Hamid, \& Yatim, 2017), Return on Equity (ROE) as in works of (Ramlee \& Ahmad, 2015; Pagach \& Warr, 2010; Alawattegama, 2018), Tobin's Q used by (Ramlee \& Ahmad, 2015; Anton, 2018; Kakanda, Salim, \& Chandren, 2016; Jafari, Chadegani, \& Biblari, 2011; Husaini \& Saiful, 2017).

\subsection{Theoretical Review}

This study is built on the legitimacy theory. Like the relationship between the agent and the principal in agency theory, so there is a relationship between the enterprise and the society in legitimacy theory. Legitimacy theory is established on the ground that the activity of an organisation is appropriate, right and good in line with the socially build system of norms, values, and beliefs of the society (Suchman, 1995). In a different view, Deegan, Rankin and Voght (2000) posit that legitimacy theory is a social contract between a firm and the larger society. Notably, legitimacy theory targets to managing the relationships among the stakeholders that are of critical importance to the existence and continuity of the enterprise. It is worthy to mention that legitimacy is assumed problematic because the societies' expectations change over time and are uncertain (Ashforth \& Gibbs, 1990). Therefore, the organization must in compliance with the societal change of expectations, change so as to be aware current happenings.

Sequel to the world financial crises of 2008, COSO (2004) came up with ERM framework as a way to handle the risk of organization holistically on a wide-array enterprise base. Subsequently, rating agencies started incorporating adoption of ERM as one of the bases for scaling. Therefore, most of the companies that implemented this ERM in their policies did that not because it is convenient and profitable to them, but due to the need and or attempt to influence the stakeholders about the legitimacy of their operations. That bring us to the stand point 
of Dowling and Pfeffer (1975), that legitimacy theory is a condition in which a firm's value system is congruent with the value system of the larger society. It therefore becomes paramount that every entity, in order to align with the expectation of the society now, ought to adopt the ERM to boast their legitimacy stand. When the desirable and proper actions are not taken, Sethi (1979) maintains that actual or potential disparity exists between the organization and social value, and organizational legitimacy will be at jeopardy, giving rise to legitimacy gap.

Relatively, the society view ERM as a system that checks the entity's risk holistically and as well see board of directors as watchdog over management. It therefore becomes imperative that organisation should adopt ERM and allow its board to be efficient in its implementation, as such makes the enterprise have legitimacy appearance before the society.

\subsection{Empirical Studies}

Altanashat, Dubai and Alhety (2019) x-rayed the impact of ERM on the institutional performance of Jordanian public shareholding companies using 313 questionnaires. The data were analysed with Structural Equation Modeling Tool (Smart-PLS) and they found that ERM implementations (Internal Environment, Event Identification, Risk Assessment, Risk Response, Control Activities, Information and Communication, and Monitoring) enhances institutional performance.

Rao (2018) investigated the joint impact of ERM and corporate governance on the value of firms operating within Gulf Cooperation Council (GCC) using the panel approach. They measured ERM with dummy variable, and proxy corporate governance using board size and existence of audit committee. They sampled 160 financial institutions from Bahrain, Kingdom of Saudi Arabia, Kuwait, Oman, United Arab Emirate and Qatar, the study spanned from 2004 to 2011 from the Bank Scope database. The finding indicated that most of the coefficients are significant in 3SLS-IV model in comparison with OLS model. Summarily, the result showed that adoption of ERM improves corporate governance simultaneously.

Andersson and Wallgren (2018) evaluated board gender diversity and financial performance of Swedish firms listed on the Nasdaq Stockholm. The researchers sampled 100 Swedish firms for a period of 4 years (2013-2016), wherein the longitudinal data over time (panel data) were extracted from the annual report of the firms which formed 400 firm year observations. The study measured firm performance with Tobin's $\mathrm{Q}$ and gender diversity with women in the board represented by diversity measurements Blau and Shannon indices. The output indicated that presence of one or more women has positive effect on financial performance. Again, higher gender diversity on boards influenced firm performance positively. They anchored their study on general board attribute and not risk committee who enforce risk policies.

Yang, Ishtiag and Anwar (2018) used a structural equation to evaluate ERM 
practice on firm performance. Survey research design was employed to be able to extract information from the respondents of the 69 SME sampled, who have 101 to 250 employees and in view of the above, 336 out of the 900 structured questionnaires administered were returned, while total of 304 were filled/completed correctly. The study found that ERM practices influence SMEs' competitive advantage significantly.

Nasir (2018) took a swipe on the effect of ERM on firm value of 83 non-financial natures in Pakistan from 1999 to 2015. Because he measured ERM (one of the dependent variables) with dummy variable, binary logistic regression was used for that estimation. The study evidenced that ERM enhances the shareholder s' value.

Yazid, Hassan, Mahmood, Rashid, Salleh, Ghazali and Mahmod (2018) conducted a conceptual study on ERM effectiveness from a Malaysian economy. In conclusion, the study was able to determine the organizational factors that might influence ERM effectiveness especially among companies in Malaysia. They sought to know the congruent factors for effective implementation of ERM.

Chou and Buchdadi (2017) reviewed board independence, audit committee, its committee, and meeting frequency against bank performance listed in Indonesia from 2013 to 2015. The study used the two stage least square (2SLS) and found that board independence, audit committee, its committee, meeting frequency improves bank performance.

Husaini and Saiful (2017) examined the effect of ERM and corporate governance on value of firms listed on Indonesian public listed companies. They sampled 110 companies from 2010 to 2013 by applying single-stage cluster sampling technique. The result indicated that board size, board independence increase firm value but showed that managerial ownership has inverse effect on firm value.

Kopia, Just, Gelmacher and Bubian (2017) conducted a qualitative overview on the organization performance and ERM by categorizing and evaluating their sources against limitations. The review spanned from 2010 to 2016 financial years. They were able to formulate an aggregate framework based on the findings from the reviews. Their findings indicated a multi-dimensional result from previous authors. They identified best practice approaches and a generic framework on how to use them to improve ERM-assessment in practice. Their study was a qualitative review.

Teoh, Lee and Muthuveloo (2017) in a study on ERM, strategic agility and internal audit quality of listed firms in Malaysia discovered that strategic agility has significant mediating effect between ERM and firm performance. More so, the study revealed that the moderating effect of quality of Internal Audit Function has insignificant effect on institutional performance. Majorly, the result provided statistical evidence that ERM framework has significant effect on the firms studied in Malaysia. It was their conclusion that ERM framework is an integrative risk management that has been recognized as contributor to the firm per- 
formance. They used primary data and the study was done in Asia.

\section{Research Methodology}

\subsection{Research Design, Data Collection Sources, and Population}

This paper used the Ex-post-facto research design since the data is an already existing data which make it difficult for the researcher to have direct control over it outcome. The panel data methodology was adopted so as to have a balanced approach on the construct. The three selected countries adopted are: Nigeria, Ghana, and South Africa. These countries are among the chief countries in the whole of Africa in terms of GDP rate. Holistically, out of the 32 banks in the study area, only seventeen were selected. The seventeen banks were selected with the use of filtering method which allowed us to sieve out the banks that did not meet our requirement. For instance, all the banks that have not been in operation for ten years, starting from 2009 were eliminated, some of them that did not disclose their enterprise risk management report were assumed to yet adopt the ERM, and those that did not include some information that relate to our driver-variables (example-educational backgrounds of the directors) were eliminated as well. After eliminating the banks with missing data, we were left with a total of seventeen banks as the sample size.

Meanwhile, data was sourced from the annual reports from the study area from 2009 to 2018 .

\subsection{Data Analysis Techniques and Model Specification}

The model used for the study is therefore stated below (Table 1):

$$
\begin{array}{r}
\text { ROE }=f(\text { ERM }[\text { i.e. strategy, operation, reporting, compliance], } \\
\text { Cosize, Codilig, Cocomp, Cogend, Coexpe, Lev, Fs })
\end{array}
$$

Presented in econometric form as;

$$
\begin{aligned}
\mathrm{ROE}_{i t}= & \beta_{0}+\beta_{1} \mathrm{ERM}_{i t}[\text { strategy } \text { operation }+ \text { reporting }+ \text { compliance }] \\
& +\beta_{2} \operatorname{Cosize}_{i t}+\beta_{3} \operatorname{Codilig}_{i t}+\beta_{4} \text { Cocomp }_{i t}+\beta_{5} \operatorname{Cogend}_{i t} \\
& +\beta_{6} \operatorname{Coexpe}_{i t}+\beta_{7} \operatorname{Lev}_{i t}+\beta_{8} \mathrm{Fs}_{i t}+\varepsilon_{i t}
\end{aligned}
$$

where;

$$
\begin{aligned}
& \text { ROE = Return on Equity } \\
& \text { ERM = ERM } \\
& \text { Cosize = Risk Committee Size } \\
& \text { Codilig = Risk Committee Diligence } \\
& \text { Cocomp = Risk Committee Composition } \\
& \text { Cogend = Risk Committee Gender Diversification } \\
& \text { Coexpe = Risk Committee Expertise } \\
& \text { Lev = Leverage } \\
& \text { Fs = Firm Size } \\
& B=\text { constant } \\
& \mathcal{E}=\text { Error term }
\end{aligned}
$$


Table 1. Operationalization of variables.

\begin{tabular}{|c|c|c|c|}
\hline Variables/specifications & $\begin{array}{l}\text { Expected } \\
\text { signs }\end{array}$ & Measurements & Authors \\
\hline Return on Equity (ROE) & & Net income divided by shareholders equity & $\begin{array}{l}\text { Ramlee and Ahmad (2015); } \\
\text { Pagach and Warr (2010) }\end{array}$ \\
\hline $\begin{array}{c}\text { Enterprise Risk } \\
\text { Management (ERM) }\end{array}$ & + & 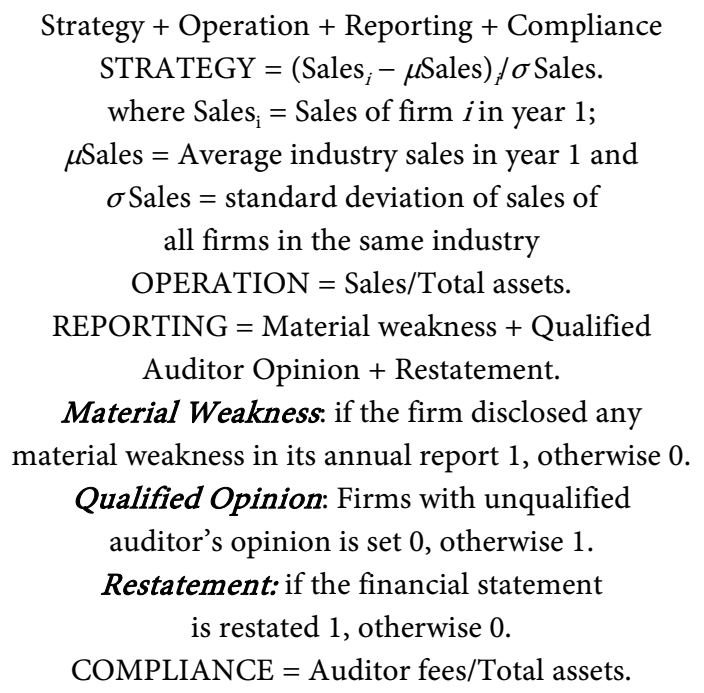 & $\begin{array}{c}\text { Zuo, Isa and } \\
\text { Rahman, (2017); } \\
\text { Gordon, Loeb } \\
\text { and Tseng (2009) }\end{array}$ \\
\hline $\begin{array}{l}\text { Risk Committee } \\
\text { Size (Cosize) }\end{array}$ & + & $\begin{array}{l}\text { Total number of directors in } \\
\text { risk management committee }\end{array}$ & $\begin{array}{l}\text { Rashid, Ibrahim } \\
\text { and Othman (2012) }\end{array}$ \\
\hline $\begin{array}{c}\text { Risk Committee } \\
\text { Diligence (Codilig) }\end{array}$ & + & $\begin{array}{l}\text { Number of meetings held and attended by the } \\
\text { committee and committee members in a year }\end{array}$ & $\begin{array}{l}\text { Allegrini and Greco (2013); } \\
\text { Saleh, Iskandar and } \\
\text { Rahmat (2007) }\end{array}$ \\
\hline $\begin{array}{c}\text { Risk Committee } \\
\text { Composition (Cocomp) }\end{array}$ & + & $\begin{array}{l}\text { The propoprtion of non-executive directors to total } \\
\text { of directors in the risk management committee }\end{array}$ & $\begin{array}{l}\text { Husaini and Saiful (2017); } \\
\text { Dionne and Triki (2005) }\end{array}$ \\
\hline $\begin{array}{l}\text { Risk Committee Gender } \\
\text { Diversification (Cogend) }\end{array}$ & + & $\begin{array}{l}\text { Dichotomous variable, where } 1 \text { indicates } \\
\text { the existence of female members in risk } \\
\text { management committee, otherwise } 0\end{array}$ & Abdullah and Ismail (2015) \\
\hline $\begin{array}{l}\text { Risk Committee } \\
\text { Expertise (Coexpe) }\end{array}$ & + & $\begin{array}{l}\text { The proportion of directors with financial expert } \\
\text { to the total directors in the committee. }\end{array}$ & Dionne and Triki (2005) \\
\hline Firm size & + & Log of total assets & Rao (2018) \\
\hline Leverage & - & Total Debt divide by total equity & $\begin{array}{l}\text { Andersson and } \\
\text { Wallgren (2018) }\end{array}$ \\
\hline
\end{tabular}

Source: Researcher's compilation (2020).

\section{Results and Discussions}

This section began with a descriptive statistics of all the study variables, followed by discussions of the panel results from each of the selected countries, followed by a comparative analysis of all the countries' results.

From Table 2 above, the descriptive statistics of the nations under study (Nigeria, South Africa and Ghana) indicates that Ghana has average ROE of $0.2 \%$, maximum of $0.4 \%$ and minimum of $-0.24 \%$. The result shows that Ghana's firms generate more returns to shareholders than Nigerian firms. South Africa 
Table 2. Country based descriptive statistics.

\begin{tabular}{ccccccccc}
\hline & Stats & ROE & Cosize & Codilig & Cocomp & Coexpert & Cogend & ERM \\
\hline & Mean & 0.1985 & 4.2 & 3.88 & 0.868 & 0.382 & 0.7 & 0.2113 \\
GHANA & Max & 0.395 & 8 & 7 & 1 & 1 & 1 & 2.376 \\
& Min & -0.237 & 3 & 3 & 0.667 & 0 & 0 & -1.0899 \\
\hline & Mean & 0.28858 & 5.86 & 4.88 & 0.9246 & 0.4322 & 0.62 & 0.790 \\
SOUTH & Max & 1.5 & 9 & 9 & 1 & 0.857 & 1 & 3.704 \\
AFRICA & Min & 0.092 & 3 & 2 & 0.667 & 0.2 & 0 & 0.564 \\
\hline & Mean & 0.07 & 6.64 & 3.98 & 0.60 & 0.3915 & 0.9 & 0.67 \\
NIGERIA & Max & 0.326 & 9 & 7 & 1 & 1 & 1 & 2.91 \\
& Min & -2.207 & 4 & 2 & 0.333 & 0.125 & 0 & -0.844 \\
\hline COUNT & 50 & 50 & 50 & 50 & 50 & 50 & 50 & 50 \\
FOR ALL & 50 & & & & & & & \\
\hline
\end{tabular}

Source: Author's compilation (2020).

has average ROE of $0.29 \%$ and maximum of 1.5 , this proves that South African firms had the best earning capacity within the periods covered by ensuring that shareholders wealth was greatly maximized. Then Nigerian firms operated on the average performance of $0.07 \%$ return on equity. This study shows that the shareholders in Nigeria were worse off to compare to other two countries since their average ROE is just $35 \%$ and $24 \%$ of ROE of Ghana and South Africa respectively. Worst still, Nigerian banks had the least ROE of -2.207 within the period under review.

On Table 3 is presented the regression result of firms (banks) in Ghana. The result indicates that the F-statistics of $3.03(0.000)$ and $40.46(0.0000)$. The regressors have the power of explaining $39 \%$ and $24 \%$ for FE and RE results respectively, of the changes in ROE of the firms. The Hausman Test probability (Prob $>$ chi2 $=0.13$ ) allowed us to choose random effect model as a preferred one over fixed effect model for the interpretation.

In that sense, risk committee size $\{$ Cosize $=0.022(0.056)\}$ of the firms in Ghana have positive and significant effect on the firms' earning capacity at $10 \%$ level, though our acceptance level is $5 \%$. Showing that firms that have risk committee size above the industry average of 4 , would likely have more quality input/contribution by the risk committee, which would result to greater earning capacity. The frequency of risk committee meetings (Codilig $=-0.051\{0.02\}$ ) has inverse and statistical significant effect on ROE at $5 \%$ level. It implies that too frequenting of meetings will amount to counter-productive therefore; minimal meetings should be attended and should not be above their average of 4 times, otherwise the value created by risk committee meetings would diminish. The Cocomp $=-0.30\{0.076\})$ indicates that independent directors has inverse significant effect on ROE at $10 \%$ level. This implies that in Ghana, more 
Table 3. Ghana panel regression.

\begin{tabular}{|c|c|c|}
\hline & $\begin{array}{c}\text { ROE Model } \\
\text { (Fixed Effect Result) }\end{array}$ & $\begin{array}{c}\text { ROE Model } \\
\text { (Random Effect Result) }\end{array}$ \\
\hline $\mathrm{C}$ & $\begin{array}{c}3.672 \\
(0.004)^{\star * *}\end{array}$ & $\begin{array}{c}1.075 \\
(0.021)^{\star *}\end{array}$ \\
\hline Cosize & $\begin{array}{c}0.086 \\
(0.006)^{\star * *}\end{array}$ & $\begin{array}{c}0.021 \\
(0.056)^{\star}\end{array}$ \\
\hline Codilig & $\begin{array}{c}-0.066 \\
(0.004)^{* * *}\end{array}$ & $\begin{array}{l}-0.051 \\
(0.02)^{\star *}\end{array}$ \\
\hline Cocomp & $\begin{array}{l}-0.151 \\
(0.589)\end{array}$ & $\begin{array}{c}-0.302 \\
(0.076)^{\star}\end{array}$ \\
\hline Coexpert & $\begin{array}{l}0.170 \\
(0.16)\end{array}$ & $\begin{array}{l}0.009 \\
(0.88)\end{array}$ \\
\hline Cogend & $\begin{array}{c}0.017 \\
(0.717)\end{array}$ & $\begin{array}{l}-0.04 \\
(0.35)\end{array}$ \\
\hline ERM & $\begin{array}{c}0.022 \\
(0.413)\end{array}$ & $\begin{array}{c}0.0559 \\
(0.034)^{\star *}\end{array}$ \\
\hline Lev & $\begin{array}{c}0.029 \\
(0.081)^{\star}\end{array}$ & $\begin{array}{c}0.016 \\
(0.179)\end{array}$ \\
\hline Fs & $\begin{array}{c}-0.146 \\
(0.005)^{\star * *}\end{array}$ & $\begin{array}{c}-0.023 \\
(0.14)\end{array}$ \\
\hline F-statistics & $\begin{array}{c}3.03 \\
(0.0101)^{* * *}\end{array}$ & $\begin{array}{c}40.46 \\
(0.0000)^{\star * *}\end{array}$ \\
\hline R-squared & 0.395 & 0.24 \\
\hline Hausman Test & \multicolumn{2}{|c|}{ Prob $>$ chi $2=0.13$} \\
\hline
\end{tabular}

Source: Author's compilation (2020). Remarks: $(1)^{*},{ }^{* *},{ }^{* *}$ means-statistical significance at $10 \%, 5 \%$ and $1 \%$ level respectively. (2) Brackets ()-represents $P$-values.

selection of independent directors might elude them some information that might necessitate certain decision on risk attitude of the enterprise. The result stands to prove that a $1 \%$ increase in independent director will cause a 0.3 unit fall in the mean of ROE of the firms in Ghana. More so, risk committee expertise (Coexpert $=0.009\{0.88\})$ indicates that account or finance expertise of the risk committee members does not significantly affect ROE and projects a positive infinitesimal figure of 0.009 on earning capacity of firms in Ghana. Similarly, risk committee gender diversification (Cogend $=-0.04$ [0.35]) affect earning capacity in Ghana negatively and is insignificant Ghana. Finally, ERM has affect banks' earning capacity in Ghana positively. What a good news that ERM implemented is impacting very significantly. Additionally, firm size and leverage are significantly affecting performance of firms in Ghana.

Table 4 contains the regression result of South African firms (banks) studied. The table shows that the F-statistics $5.58(0.0000)$ and $68.81(0.0000)$ for fixed effect and random effect models respectively indicate that the models are valid 
Table 4. South Africa panel regression.

\begin{tabular}{|c|c|c|}
\hline & $\begin{array}{c}\text { ROE Model } \\
\text { (Fixed Effect Result) }\end{array}$ & $\begin{array}{c}\text { ROE Model } \\
\text { (Random Effect Result) }\end{array}$ \\
\hline $\mathrm{C}$ & $\begin{array}{l}-0.58 \\
(0.72)\end{array}$ & $\begin{array}{c}1.30 \\
(0.11)\end{array}$ \\
\hline Cosize & $\begin{array}{l}0.009 \\
(0.76)\end{array}$ & $\begin{array}{c}-0.06 \\
(0.038)^{\star *}\end{array}$ \\
\hline Codilig & $\begin{array}{c}-0.012 \\
(0.72)\end{array}$ & $\begin{array}{l}0.025 \\
(0.48)\end{array}$ \\
\hline Cocomp & $\begin{array}{c}1.5 \\
(0.000)^{\star * *}\end{array}$ & $\begin{array}{c}1.355 \\
(0.003)^{\star * *}\end{array}$ \\
\hline Coexpert & $\begin{array}{c}0.389 \\
(0.10)^{\star}\end{array}$ & $\begin{array}{c}1.02 \\
(0.000)^{\star * *}\end{array}$ \\
\hline Cogend & $\begin{array}{c}0.11 \\
(0.22)\end{array}$ & $\begin{array}{c}0.38 \\
(0.000)^{\star * \star}\end{array}$ \\
\hline ERM & $\begin{array}{c}0.11 \\
(0.033)^{\star *}\end{array}$ & $\begin{array}{c}0.115 \\
(0.063)^{\star}\end{array}$ \\
\hline Lev & $\begin{array}{l}0.014 \\
(0.55)\end{array}$ & $\begin{array}{c}-0.016 \\
(0.13)\end{array}$ \\
\hline Fs & $\begin{array}{c}-0.038 \\
(0.57)\end{array}$ & $\begin{array}{c}-0.105 \\
(0.001)^{\star * \star}\end{array}$ \\
\hline F-statistics & $\begin{array}{c}5.58 \\
(0.000)\end{array}$ & $\begin{array}{c}68.81 \\
(0.000)\end{array}$ \\
\hline R-squared & 0.56 & 0.37 \\
\hline Hausman Test & \multicolumn{2}{|c|}{ Prob $>$ chi $2=0.000^{* * *}$} \\
\hline
\end{tabular}

Source: Author's compilation (2020). Remarks: (1) ${ }^{*}{ }^{* *},{ }^{* * *}$ means-statistical significance at $10 \%, 5 \%$ and $1 \%$ level respectively. (2) Brackets ()-represents $P$-values.

for making inferences, as they are both statistically significant at $1 \%$ level. The R-square of $56 \%$ and $37 \%$ for fixed effect and random effect results show that the models maintain goodness of fit for predicting the dependent variable (ROE). Hausman Test (Prob $>$ chi $2=0.000)$ proves statistically significant at $1 \%$ level, therefore directs that fixed effect model is preferable to random effect. Sequel to this, our interpretation is based on fixed effect model result.

From the result in Table 4, it is seen that risk committee size (Cosize $=0.009$ $\{0.76\}$ ) has infinitesimal positive and insignificant effect on ROE. Frequency of meetings by risk committee (Codilig $=-0.012\{0.72\}$ ) shows that many meetings by the committee in a year will only reduce the value of ROE of the firms in South Africa. It shows that risk committee meetings do not have any significant effect on ROE of the firms. But risk committee composition (Cocomp $=1.5$ $\{0.000)\}$, risk committee expertise (Coexpert $=0.39\{0.10\}$ ), and enterprise risk management $(\mathrm{ERM}=0.11\{0.03\})$ have all positive and statistical significant effect on ROE at $1 \%, 10 \%$ and $5 \%$ levels respectively. More so, presence of women 
in the board (Cogend $=0.11\{0.22\}$ ) has positive but not significantly associating with ROE. Among the variables, proportion of independent directors to aggregate directors has a high magnitude impact on ROE and it's evidenced by their high average involvement of independent directors in the risk committee to the extent of $92 \%$, which is far above what is obtainable in other countries. In addition, firm size and leverage have negative effect on ROE, though only firm size is significant at $1 \%$ level.

Looking at Nigeria firms' result in Table 5, we observed that F-statistics values $8.47(0.000)$ and $84.26(0.000)$ for fixed effect and random effect models respectively indicate that the models are valid for drawing inferences since they are both highly statistically significant at $1 \%$ level. The $\mathrm{R}$-Squared $\left(\mathrm{R}^{2}\right)$ is observed to be $65 \%$ and $60 \%$ for FE and RE models respectively, which shows that our models are fit for explaining the changes in the dependent variable. The Hausman Test value (Prob $>$ chi $2=0.716$ ) indicates thattheRE for our interpretation.

Table 5. Nigeria panel regression.

\begin{tabular}{|c|c|c|}
\hline & $\begin{array}{c}\text { ROE Model } \\
\text { (Fixed Effect Result) }\end{array}$ & $\begin{array}{c}\text { ROE Model } \\
\text { (Random Effect Result) }\end{array}$ \\
\hline $\mathrm{C}$ & $\begin{array}{c}-8.39 \\
(0.002)^{* * *}\end{array}$ & $\begin{array}{c}-4.11 \\
(0.002)^{\star * *}\end{array}$ \\
\hline Cosize & $\begin{array}{c}-0.10 \\
(0.053)^{\star *}\end{array}$ & $\begin{array}{c}-0.047 \\
(0.16)\end{array}$ \\
\hline Codilig & $\begin{array}{c}-0.132 \\
(0.042)^{\star *}\end{array}$ & $\begin{array}{l}-0.135 \\
(0.03)^{\star \star}\end{array}$ \\
\hline Cocomp & $\begin{array}{l}-0.553 \\
(0.158)\end{array}$ & $\begin{array}{l}-0.34 \\
(0.24)\end{array}$ \\
\hline Coexpert & $\begin{array}{l}0.364 \\
(0.28)\end{array}$ & $\begin{array}{c}0.38 \\
(0.082)^{\star}\end{array}$ \\
\hline Cogend & $\begin{array}{c}0.18 \\
(0.21)\end{array}$ & $\begin{array}{c}0.279 \\
(0.038)^{\star *}\end{array}$ \\
\hline ERM & $\begin{array}{c}0.12 \\
(0.051)^{*}\end{array}$ & $\begin{array}{l}0.061 \\
(0.24)\end{array}$ \\
\hline Lev & $\begin{array}{c}-0.157 \\
(0.000)^{* * *}\end{array}$ & $\begin{array}{c}-0.125 \\
(0.000)^{\star * \star}\end{array}$ \\
\hline Fs & $\begin{array}{c}0.375 \\
(0.001)^{\star * *}\end{array}$ & $\begin{array}{c}0.197 \\
(0.000)^{\star \star *}\end{array}$ \\
\hline F-statistics & $\begin{array}{c}8.47 \\
(0.0000)^{\star * *}\end{array}$ & $\begin{array}{c}84.26 \\
(0.0000)^{\star * *}\end{array}$ \\
\hline R-squared & 0.65 & 0.60 \\
\hline Hausman Test & \multicolumn{2}{|c|}{ Prob $>$ chi $2=0.716$} \\
\hline
\end{tabular}

Source: Author's compilation (2020). Remarks: (1) ${ }^{*}{ }^{* *},^{* * *}$ means-statistical significance at $10 \%, 5 \%$ and $1 \%$ level respectively. (2) Brackets ()-represents $P$-values. 
Risk committee size of Nigerian banks (Cosize $=-0.047\{0.16\}$ ) has negative insignificant effect on earning capacity of the firms. Frequency of meetings by risk committee (Codilig $=-0.135\{0.03\}$ ) did also show an inverse significant effect on banks' earning capacity just like those in Ghana and South Africa. Committee composition $\{$ Cocomp $=-0.34(0.24)\}$ has inverse and no significant effect on ROE. Account expertise of risk committee members $\{$ Coexpert $=0.38$ $(0.082)\}$ affects ROE both positively but was insignificant. Hence if firms in Nigeria can engage more or only directors with account knowledge in its risk committee, it would help banks reduce risks to its acceptable risk appetite, as well increase the earning capacity of the banks. Imagine where a unit increase in member with account expertise can increase ROE by 0.38 units if other study variables equals zero. Moreover, Nigeria firms have just engaged on the average, $40 \%$ of the directors with account expertise to their risk committee, leaving out large unused gaps for account expertise, which can increase performance when maximally used. Inclusion of women in the risk committee \{Cogend $=0.279$ $(0.038)\}$ produced positive and significant effect on ROE at $5 \%$ level. Nigeria has done more than other nations in this regard by engaging women in its risk committee for $90 \%$ of its firms-year observation of 50. (i.e. women are involved in risk committee for 45 out of 50 observations). Finally, ERM value 0.061 (0.24) discloses positive but insignificant effect on Nigerian firms' earning capacity. The control variables firm size and leverage have significant effect both at 5\% level on ROE, firm size affects positively while leverage affects negatively (Table $6)$.

Having looked at how our explanatory variables fit to explain the earning capacity of firms (banks) as was measured with ROE across Ghana, South Africa and Nigeria, we can conclude that our regressors have greatest effect on firms' earning capacity in Nigeria $\left(\mathrm{R}^{2}=60 \%\right)$. More so, our model has shown that South Africa has performed on a closer chase to Nigeria, in generating returns to the shareholders using the regressors mentioned $\left(R^{2}=56 \%\right)$. Finally, Ghana has performed the least so to say as the same variables generated or made the least input to $\mathrm{ROE}\left(\mathrm{R}^{2}=24 \%\right)$.

\section{Conclusions and Recommendations}

This study did a comparative analysis on the effect of ERM, risk committee, on

Table 6. Country summary table.

\begin{tabular}{cccc}
\hline & GHANA & SOUTH AFRICA & NIGERIA \\
\hline F-STATISTICS & 40.46 & 5.58 & 84.26 \\
$P$-VALUE & 0.0000 & 0.0000 & 0.0000 \\
R-SQUARE & 0.24 & 0.56 & 0.60 \\
MODEL & RANDOM EFFECT & FIXED EFFECT & RANDOM EFFECT \\
\hline
\end{tabular}

Source: Author's compilation (2020). 
earning capacity of African banks. The study covered a study period of ten (10) years spanning from 2009 to 2018. The study found that both ERM and risk committee efficiency have the greatest effect on the earning capacity of Nigerian firms $\left(\mathrm{R}^{2}=60 \%\right)$ than the rest two countries. More so, our model has shown that South Africa has performed on a closer chase to Nigeria, in generating returns to the shareholders using the regressors mentioned above $\left(\mathrm{R}^{2}=56 \%\right)$. Finally, Ghana has performed the least so to say as the same variables generated or made the least input to ROE $\left(\mathrm{R}^{2}=24 \%\right)$. Hence, we conclude ERM and risk committee are instrumental to improved earnings capacity of selected African banks. As such, we recommend that:

1) Regulators in African countries should enforce strict compliance and ensure that the ERM policies are implemented across banks in Africa. For instance, it could be added to the purview of NDIC to regulate ERM implementation in Nigeria, such responsibility could be given to Securities and Exchange Commission in Ghana and South African Reserve Bank (SARB) for banks in South Africa.

2) A minimum of 6 members should constitute a committee.

3) Corporate board should engage men that are knowledgeable in risk management.

4) Committee chairmen should appoint managers that are knowledgeable in accounting.

5) The board of directors should strive to carry out their monitoring functions effectively and ensure that ERM scheme of the enterprise is rolled out religiously on all associated risk matters of the enterprise.

Contributively, this study has made a tremendous contribution to knowledge in various ways as outlined below;

1) This study is the first of its kind on a larger scope in African continent (Ghana, South Africa and Nigeria), therefore was able to make comparison among these nations.

2) Having seen the broad study done in USA and Gulf Corporation Council by Kommunuri, Jandug and Vesty (2014) and Rao (2018) respectively, where they examined the joint impact of ERM and board effectiveness on firm value. Our study replicated the research in African continent by investigating the interaction of risk management committee effectiveness and ERM on firm performance using samples from Ghana, South Africa and Nigeria. Therefore, this study is the first to the best of our knowledge to have carried out such broad study in Africa.

3) This study has established a foundation and points to a direction that can assist researchers to take up a new study on the topic.

\section{Limitations of the Study}

Our major challenge was that only banking sector across the African nations chosen had implemented ERM. Again, the study was set to run a balanced panel data analysis, that made us filter out the banks without complete information 
disclosure on the variables of the study and that brought the sample to a relatively low size. Hence, we suggest that other researchers can take a pooled data approach on banks as well as include other sectors that may have adopted ERM, to know their effect on earnings capacity.

\section{Conflicts of Interest}

The authors declare no conflicts of interest regarding the publication of this paper.

\section{References}

Abdullah, A., \& Ismail, K. N. (2015). Hedging Activities Information and Risk Management Committee Effectiveness: Malaysian Evidence. Australian Journal of Basic and Applied Sciences, 9, 211-219.

Abdullah, H. S. B., Janor, H., Hamid, M. A., \& Yatim, P. (2017). The Effect of Enterprise Risk Management on Firm Value: Evidence from Malaysian Technology. Jurnal Pengurusan, 49, 3-11. https://doi.org/10.17576/pengurusan-2017-49-01

Ahmed, H. A., Abdullahi, B. A., Mohamed, I. M., \& Umar, A. M. (2018). The Effect of Risk Management Committee Attributes and Board Financial Knowledge on the Financial Performance of Listed Banks in Nigeria. American International Journal of Business Management, 1, 7-13.

Alawattegama, K. K. (2018). The Effect of Enterprise Risk Management (ERM) on Firm Performance: Evidence from the Diversified Industry of Sri Lanka. Journal of Management Research, 10, 75-93. https://doi.org/10.5296/jmr.v10i1.12429

Allegrini, M., \& Greco, G. (2013). Corporate Boards, Audit Committees and Voluntary Disclosure: Evidence from Italian Listed Companies. Journal of Management and Governance, 17, 187-216. https://doi.org/10.1007/s10997-011-9168-3

Altanashat, M., Dubai, M., \& Alhety, S. (2019). The Impact of Enterprise Risk Management on Institutional Performance in Jordanian Public Shareholding Companies. Journal of Business and Retail Management Research, 13, 256-268. https://doi.org/10.24052/JBRMR/V13IS03/ART-23

Andersson, P., \& Wallgren, F. M. (2018). Board Gender Diversity and Firm Financial Performance. Unpublished Master Thesis Submitted to the Department of Business Administration, JÖNKÖPING University, Jönköping International Business School.

Anton, S. G. (2018). The Impact of Enterprise Risk Management on Firm Value: Empirical Evidence from Romanian Non-Financial Firms. Inzinerine Ekonomika-Engineering Economics, 29, 151-157. https://doi.org/10.5755/j01.ee.29.2.16426

Ashforth, B. E., \& Gibbs, B. W. (1990). The Double-Edge of Organizational Legitimation. Organization Science, 1, 177-194. https://doi.org/10.1287/orsc.1.2.177

Battaglia, F., Gallo, A., \& Graziano, A. E. (2014). Strong Boards, Risk Committee and Bank Performance: Evidence from India and China. In S. Boubaker, \& D. Nguyen (Eds.), Corporate Governance in Emerging Markets (pp. 79-105). Springer. https://doi.org/10.1007/978-3-642-44955-0_4

Chou, T. K., \& Buchdadi, A. D. (2017). Independent Board, Audit Committee, Risk Committee, the Meeting Attendance Level and Its Impact on the Performance: A Study of Listed Banks in Indonesia. International Journal of Business Administration, 8, 24-36. https://doi.org/10.5430/ijba.v8n3p24

COSO (Committee of Sponsoring Organizations of the Treadway Commission) (2004, 
September) Enterprise Risk Management-Integrated Framework: Executive Summary. http://www.coso.org

Dabari, I. J., \& Saidin, S. Z. (2016). A Moderating Role of Board Characteristics on Enterprise Risk Management Implementation: Evidence from the Nigeria Banking Sector. International Journal of Economics and Financial Issues, 6, 96-103.

Deegan, C., Rankin, M., \& Voght, P. (2000). Firms Disclosure Reactions to Major Social Incidents: Australian Evidence. Accounting Forum, 24, 101-130.

Dionne, G., \& Triki, T. (2005). Risk Management and Corporate Governance: The Importance of Independence and Financial Knowledge for the Board and the Audit Committee. SSRN Electronic Journal, 1-79. https://doi.org/10.2139/ssrn.686470

Dowling, J., \& Pfeffer, J. (1975). Organisational Legitimacy: Social Values and Organisational Behaviour. Pacific Sociological Review, 18, 122-136.

https://doi.org/10.2307/1388226

Florio, C., \& Leoni, G. (2017). Enterprise Risk Management and Firm Performance: The Italian Case. The British Accounting Review, 49, 56-74. https://doi.org/10.1016/j.bar.2016.08.003

Gordon, L. A., Loeb, M. P., \& Tseng, C. Y. (2009). Enterprise Risk Management and Firm Performance: A Contingency Perspective. Journal of Account, Public Policy, 28, 301-327. https://doi.org/10.1016/j.jaccpubpol.2009.06.006

Husaini, \& Saiful. (2017). Enterprise Risk Management, Corporate Governance and Firm Value: Empirical Evidence from Indonesian Public Listed Companies. International Journal of Advances in Management and Economics, 6, 16-23.

Jafari, M., Chadegani, A. A., \& Biglari, V. (2011). Effective Risk Management and Company's Performance: Investment in Innovations and Intellectual Capital Using Behavioral and Practical Approach. Journal of Economics and International Finance, 3, 780-786.

Kakanda, M. M., Salim, B., \& Chandren, S. (2016). Review of the Relationship between Board Attributes and Firm Performance. Asian Journal of Finance \& Accounting, 8, 168-181. https://doi.org/10.5296/ajfa.v8i1.9319

Kommunuri, J., Jandug, L., \& Vesty, G. (2014). Risk Management, Board Effectiveness and Firm Value: Evidence from S\&P/ASx200 Companies. SSRN Electronic Journal. https://doi.org/10.2139/ssrn.2542023

Kopia, J., Just, V., Geldmacher, W., \& Bubian, A. (2017). Organization Performance and Enterprise Risk Management. EGOFORUM, 6, 1-14.

Lai, F. W., \& Samad, F. A. (2011). Enterprise Risk Management Framework and the Empirical Determinants of Its Implementation. International Conference on Business and Economics Research, 1, 340-344.

Liebenberg, A. P., \& Hoyt, R. E. (2003). The Determinants of Enterprise Risk Management: Evidence from the Appointment of Chief Risk Officers. Risk Management and Insurance Review, 6, 37-52. https://doi.org/10.1111/1098-1616.00019

Lukianchuk, G. (2015). The Impact of Enterprise Risk Management on Firm Performance of Small and Medium Enterprises. European Scientific Journal, 11, 408-427.

Mikes, A., \& Kaplan, R. R. (2014). Towards a Contingency Theory of Enterprise Risk Management (pp. 1-45). Working Paper 13-063, Harvard Business School.

Nasir, N. (2018). Effect of Enterprise Risk Management on Firm Value: Empirical Evidence from Non-Financial Firms in Pakistan. A Master's Degree Thesis to Faculty of Management Sciences, Capital University of Science and Technology.

Naz, F., Ijaz, F., \& Naqvi, F. (2016). Financial Performance of Firms: Evidence from Pa- 
kistan Cement Industry. Journal of Teaching and Education, 5, 81-94.

Omondi, M. M., \& Muturi, W. (2013). Factors Affecting the Financial Performance of Listed Companies at the Nairobi Securities Exchange in Kenya. Research Journal of Finance and Accounting, 4, 99-105.

Onder, S., \& Ergin, H. (2012). Determiners of Enterprise Risk Management Applications in Turkey: An Empirical Study with Logistic Regression Model on the Companies Included in ISE (Istanbul Stock Exchange). Business and Economic Horizons, 7, 19-26.

Paape, L., \& Spekle, R. F. (2012). The Adoption and Design of Enterprise Risk Management Practices: An Empirical Study. European Accounting Review, 21, 533-564. https://doi.org/10.1080/09638180.2012.661937

Pagach, D., \& Warr, R. (2010). The Effect of Enterprise Risk Management on Firm Performance. http://ssrn.com/abstract=1155218 https://doi.org/10.2139/ssrn.1155218

Pagach, D., \&Warr, R. (2007). An Empirical Investigation of the Characteristics of Firms Adopting Enterprise Risk Management. Working Paper. http://ssrn.com/abstract $=1010200$

Ramlee, R., \& Ahmad, N. (2015). Panel Data Analysis on the Effect of Establishing the Enterprise Risk Management on Firms' Performances. Proceedings of 4th European Business Research Conference Imperial College, London, UK.

Rao, A. (2018). Empirical Analysis of Joint Impact of Enterprise Risk Management and Corporate Governance on Firm Value. International Review of Advances in Business, Management and Law, 1, 34-50. https://doi.org/10.30585/irabml.v1i1.66

Rashid, A. A., Ibrahim, M. K., Othman, R., \& See, K. F. (2012). IC Disclosures in IPO Prospectuses: Evidence from Malaysia. Journal of Intellectual Capital, 13, 57-80. https://doi.org/10.1108/14691931211196213

Saleh, M. N., Iskandar, M. T., \& Rahmat, M. M. (2007). Audit Committee Characteristics and Earnings Management: Evidence from Malaysia. Asian Review of Accounting, 15, 147-163. https://doi.org/10.1108/13217340710823369

Sethi, S. P. (1979). A Conceptual Framework for Environmental Analysis of Social Issues and Evaluation of Business Response Patterns. Academy of Management Review, 4, 63-74. https://doi.org/10.2307/257404

Suchman, M. C. (1995). Managing Legitimacy: Strategic and Institutional Approaches. Academy of Management Review, 20, 571-610. https://doi.org/10.2307/258788

Teoh, A. P., Lee, K. Y., \& Muthuveloo, R. (2017). The Impact of Enterprise Risk Management, Strategic Agility, and Quality of Internal Audit Function on Firm Performance. International Review of Management and Marketing, 7, 222-231.

Tseng, C. Y. (2007). Internal Control, Enterprise Risk Management, and Firm Performance. A Ph.D. Dissertation to University of Maryland.

Udoka, C. O., \& Orok, A. B. (2017). Assessment of the Enterprise Risk Management in the Nigerian Banking Industry. Asian Journal of Economics and Empirical Research, 4, 68-74. https://doi.org/10.20448/journal.501.2017.42.68.74

Yang, S., Ishtiaq, M., \& Anwar, M. (2018). Enterprise Risk Management Practice and Firm Performance, the Mediating Role of Competitive Advantage and the Moderating Role of Financial Literacy. Journal of Risk and Financial Management, 11, Article No. 35. https://doi.org/10.3390/jrfm11030035

Yazid, A. S., Hassan, M. F., Mahmood, S., Rashid, N., Salleh, F., Ghazali, P. L., \& Mahmod, M. S. (2018). Organizational Factors in Enterprise Risk Management Effectiveness: A Conceptual Framework. International Journal of Academic Research in Busi- 
ness and Social Sciences, 8, 1437-1446. https://doi.org/10.6007/IJARBSS/v8-i11/5202

Zemzem, A., \& Kacem, O. (2014). Risk Management, Board Characteristics and Performance in the Tunisian Lending Institutions. International Journal of Finance \& Banking Studies, 3, 186-200. https://doi.org/10.20525/ijfbs.v3i1.179

Zuo, X., Isa, C. R., \& Rahman, M. (2017). Valuation of Enterprise Risk Management in the Manufacturing Industry. Total Quality Management \& Business Excellence, 30, 1389-1410. https://doi.org/10.1080/14783363.2017.1369877 